(C) Shundryk M.A., Marchenko I.Y., Tkachenko I.M., Vodoriz Y.Y., Boyko V.V.

UDC 616.313:616-07:616.711-007.5

DOI https://doi.org/10.31718/mep.2019.23.1-2.05

\title{
THE CORRESPONDENCE OF THE TONGUE CENTRAL LINE DEVIATION WITH THE PATHOLOGY OF SPINAL CURVATURE
}

\author{
Shundryk M.A., Marchenko I.Y., Tkachenko I.M., Vodoriz Y.Y., Boyko V.V.
}

Ukrainian medical stomatological academy, Poltava, Ukraine

\begin{abstract}
Наукові дослідження вказують на неправильну поставу як фактор, що впливає на виникнення аномалії оклюзії та їх ускладнення. Поверхня язика може відображати порушення травлення, серцевої діяльності, стану нервової $і$ ендокринної систем. У літературі є дані про те, що язик може допомогти в діагностиці багатьох захворювань, адже зовнішній вигляд язика в значній мірі пов'язаний з його анатомічними особливостями, а рецептори слизової оболонки мають широку кореляцію з центральною нервовою, серцево-судинною, ендокринною та, навіть, з опорноруховою системами. Мета. Визначення відповідності розташуванням серединної лінії язика ступеню викривлення хребта на різних рівнях у дітей хворих на сколіоз. Матеріали і методи. Було обстежено 56 дітей (30 дівчат, 26 хлопців) у віці 11-14 років, з тривалістю захворювання опорно-рухового апарату 1-3 роки. Кожному пацієнту було проведено огляд власне порожнини рота, язика для визначення положення серединної лінії язика. Проаналізовано рентгенологічні знімки хребта хворих досліджуваних груп. Результати. у дітей, де давність захворювання становить 1 рік порушення серединної лінії язика виявлено в 25,02\% випадків, у дітей з давністю захворювання 2 роки - в 65,52\% випадків, при тривалості захворювання 3 роки 86,66\% пацієнтів мають викривлення серединної лінії язика. Висновок. Проведене дослідження дозволяє рекомендувати лікарям - стоматологам під час проведення огляду порожнини рота звертати увагу не тільки на розмір, колір, стан сосочків язика, а й на положення середньої лінії, викривлення якої може інформувати про викривлення хребта в різних відділах. Необхідні подальші дослідження для виявлення механізмів впливу стану хребта і впливу скелетних м'язів на м'язи щелепно-лицевої ділянки, які беруть участь у формуванні оклюзії і функції органів порожнини рота.
\end{abstract}

Ключові слова: осанка, сколіоз, викривлення серединної лінії язика, захворювання опорно-рухового апарату.

Scientific researches suggest posture problems as a factor affecting the occurrence of occlusion anomalies as well as their complications. The surface of the tongue may reflect disorders in digestion, cardiac activity, nervous and endocrine systems. In the literature, there is data that the tongue can help in the diagnosis of many diseases, because its general appearance is in a significant relation with its anatomical features. Receptors of its mucous membrane are closely related to the central nervous, cardiovascular, endocrine and locomotor systems. Aim. The purpose of the study was to determine the correspondence between the location of the tongue median line and the degree of distortion of the vertebral column at different levels in children with scoliosis. Materials and methods. Totally 56 children (30 girls, 26 boys) aged 11-14 years were examined, with a duration of musculoskeletal disorders 1-3 years. For each participant, the oral cavity examination was performed, the position of the middle line of the tongue was determined. $X$-ray images of vertebral column of patients from investigated groups were analyzed. Results. In the group with 1 year duration of the disease $25.02 \%$ patients had distorted median line of the tongue, in the group with 2 years of duration of the disease $65,52 \%$ participants had the deviation of the medial line of the tongue, in the group with 3 years of duration of the disease $86.66 \%$ of patients had the deviation of the median line of the tongue. Conclusions. This research allows us to recommend paying attention not only to the size, color, state of the papillae of the tongue, but also to the position of the middle line, whose distortion may indicate the deviation of the vertebral column in different portions. Further research is needed to detect the mechanisms of influence of the spine and the influence of skeletal muscles on muscles of the maxillofacial area, which are involved in the formation of occlusion and function of the organs of the oral cavity.

Key words: posture, scoliosis, central line of the tongue deviation, musculoskeletal disorders

\section{Introduction}

Until recent years, pathologies of organs of the oral cavity and the mucouse membrane were considered as local pathological processes associated only with poor hygienic condition of the oral cavity and the negative influence of pathogenic factors. However, modern researches and experimental models of the diseases allow us to establish that the oral cavity has a close anatomical and physiological relationship with various systems of the organism [1,2, 3].

Scientific researches suggest posture problems as a factor affecting the occurrence of occlusion anomalies as well as their complications. In case of pathological occlusion (usually distal occlusion) there is an increased load on the constantly tensed occipital, scalenus, thoracicclavicular-osseous muscles due to displacement of the center of gravity of the head augmentation. [4, 5]. Taking into consideration the high mobility of the cervical portion of the vertebral column some preconditions for disfunction of all systems and organs appear; especially for those located in the maxillo-facial area and exercising on the facial skull, cranial and spinal nerves, autonomic

To cite this English version: Shundryk M.A., Marchenko I.Y., Tkachenko I.M., Vodoriz Y.Y., Boyko V.V. The correspondence of the tongue central line deviation with the pathology of spinal curvature. // The Medical and ecological problems. - 2019. - Vol 23, № 1-2. P. 22-25. 
ganglia, vascular bundles, different muscles of the mentioned area, including mylohyoid and hyoglossus muscles, which cooperate with proper longitudinal and vertical muscles of the tongue.

Even ancient physicians used the tongue to decipher diagnostic symptoms of almost any human disease from its surface. Indeed, it can be stated that disorders of various organs are usually manifested with changes in the surface of the tongue even before their pathological symptoms appear. Even with the disappearance of symptoms, the tongue may indicate that the etiology of the disease remains unresolved and the full recovery did not occur.

Increasing sensitivity and discoloration of certain parts of the tongue reflect the disturbance of those organs associated with corresponding areas on its surface.

The localization of the plaque which covers the tongue indicates the accumulation of toxins in the stomach and small intestine (if the plaque is localized in the middle part of the tongue), in the large intestine (if the plaque is localized in the distal third of the tongue).

The surface of the tongue may reflect disorders in digestion, cardiac activity, nervous and endocrine systems.

In the scientific literature, there is data that the tongue can help in the diagnosis of many diseases, because its general appearance is in a significant relation with its anatomical features. Receptors of its mucous membrane are closely related with the central nervous, cardiovascular, endocrine and locomotor systems. [3, 5]. The line which goes in the middle of it, accurately reflects the state of the human backbone. The curvature of the line on the tip of the tongue indicates the curvature of the vertebral column in the cervical portion, the one in the middle signs about problems in the thoracic part, at the root deviation corresponds to the curvature of the vertebrae in the lumbar section.

For the human spine, three moderately pronounced physiological bends are natural. Cervical spine has a curve, convex forward, that begins at the axis at the apex of the odontoid process and ends at the middle of the second thoracic vertebra (lordosis). The thoracic curve, concave forward, begins at the middle of the second and ends at the middle of the twelfth thoracic vertebra (kyphosis). The lumbar curve begins at the middle of the last thoracic vertebra and ends at the sacrovertebral angle (lordosis).

Scoliosis is a pathological lateral curvature of the vertebral column with the obligatory rotation of the vertebral bodies. The characteristic feature of which is a progression of the disease, associated with age and growth of the child.

Unfortunately, nowadays disorders of the backbone are very common among children and adolescents; especially scoliosis, which is 5-6 times more likely to occur in girls than in boys and also affects the reproductive function which makes it is a socially significant disease $[6,7]$.

Whereas the spine deformation reflects can affect the median fissure of the tongue appearance, dentists as first-line doctors communicating with wide sections of the population during examinations in kindergartens, schools or in clinics can easily suspect the pathology and inform the patient or his/her parents about it, thereby to prevent further development of the disease.

Aim
The purpose of the study was to determine the correspondence between the location of the tongue median line and the degree of distortion of the vertebral column at different levels in children with scoliosis.

\section{Materials and methods}

In order to achieve this goal, we performed our research on the basis of Poltava regional sanatorium for children with musculoskeletal disorders. Totally 56 children (30 girls, 26 boys) aged 11-14 years were examined, with duration of musculoskeletal disorders 1-3 years (Tab 1). The comparison of the location of the median line of the tongue (photos) with the position of the spine (X-ray) in different departments - cervical, thoracic, and lumbar, was also performed.

Table 1

Dispersion of patients regarding to their age and duration of the

\begin{tabular}{|c|c|c|c|c|c|}
\hline \multirow{2}{*}{ Age } & \multicolumn{2}{|c|}{ N of patients } & \multicolumn{3}{c|}{$\begin{array}{c}\text { Duration } \\
\text { of the disease } \\
\text { (years) }\end{array}$} \\
\cline { 2 - 6 } & $\mathrm{n}=56$ & $\%$ & 1 & 2 & 3 \\
\hline 11 & 11 & 19.64 & 4 & 7 & 0 \\
\hline 12 & 11 & 19.64 & 4 & 6 & 1 \\
\hline 13 & 15 & 26.74 & 3 & 7 & 5 \\
\hline 14 & 19 & 33.98 & 1 & 9 & 9 \\
\hline
\end{tabular}

\section{Results and discussion}

According to the obtained data, in can be stated that the largest number of patients were children with duration of the disease for 2 years -29 patients $(51.80 \%)$, for 1 year -12 patients $(21.42 \%), 3$ years - 15 patients $(26.78 \%)$.

In the group with 1year duration of the disease, $25,02 \%$ patients had the disrupted median line of the tongue. In the group with 2 years of duration of the disease, $65,52 \%$ participants had the deviation of the median line of the tongue. In the group with 3 years of duration of the disease, $86.66 \%$ of patients had the deviation of the median line of the tongue (Tab. 2).

Table 2

Dispersion of the patients with the central line of the tongue deviation

\begin{tabular}{|c|c|c|c|}
\hline \multirow{2}{*}{$\begin{array}{c}\text { Duration } \\
\text { of the disease } \\
\text { (years) }\end{array}$} & N of patients & \multicolumn{2}{|c|}{$\begin{array}{c}\text { N of patients with the cen- } \\
\text { tral line of the tongue de- } \\
\text { viation }\end{array}$} \\
\cline { 3 - 4 } & & $\mathrm{n}$ & $\%$ \\
\hline 1 & 12 & 3 & 25.02 \\
\hline 2 & 29 & 19 & 65.52 \\
\hline 3 & 15 & 13 & 86.66 \\
\hline
\end{tabular}

The curvature of the spine in the cervical region corresponded to the bend of the median line of the tongue in the tip region, the bend of the spine in the thoracic region corresponded to the bend of the median line of the tongue in the middle part, the bend of the spine in the lumbar region corresponded to the bend of the medianl line of the tongue in the root area (Fig.1,2,3, 4). 


\section{Tom 23, N 1-2 2019 p.}
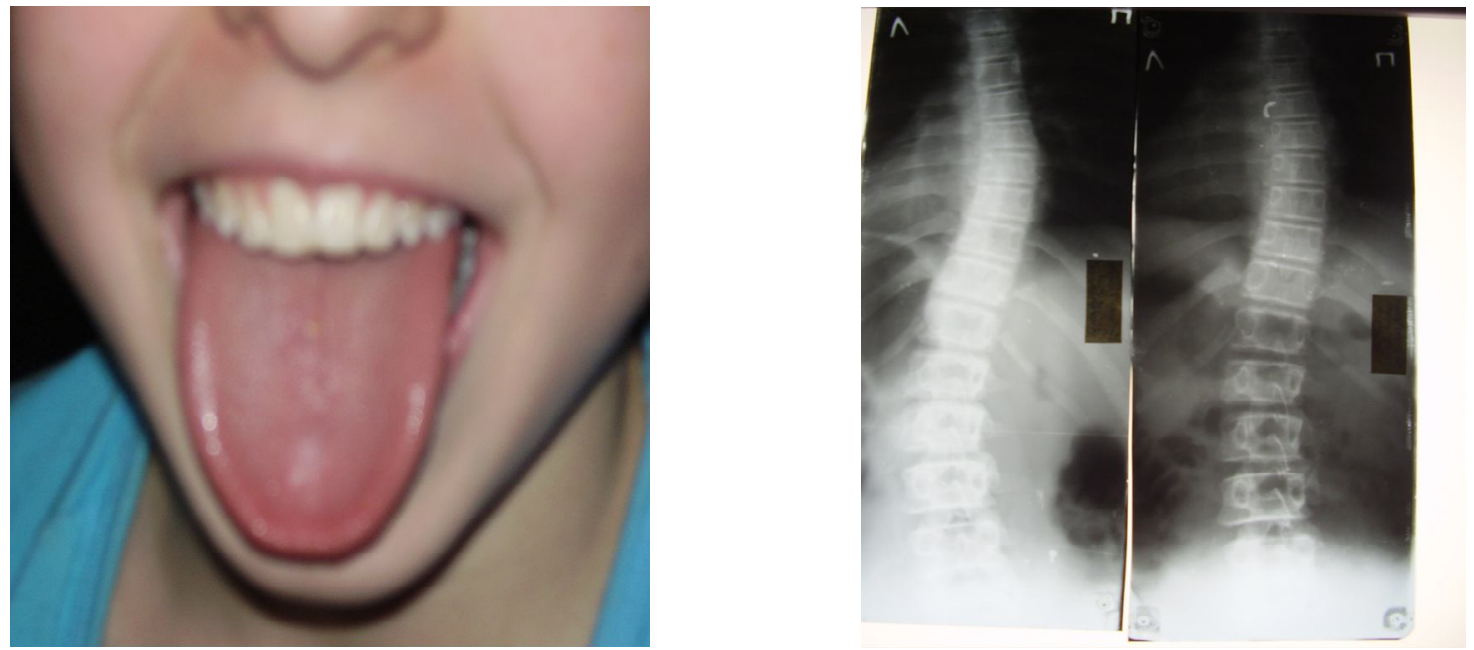

Fig. 1. Patient N., 11 years. Deviation of the middle line of the tongue in the tip corresponds to the curvature of the vertebral column in the cervical region.
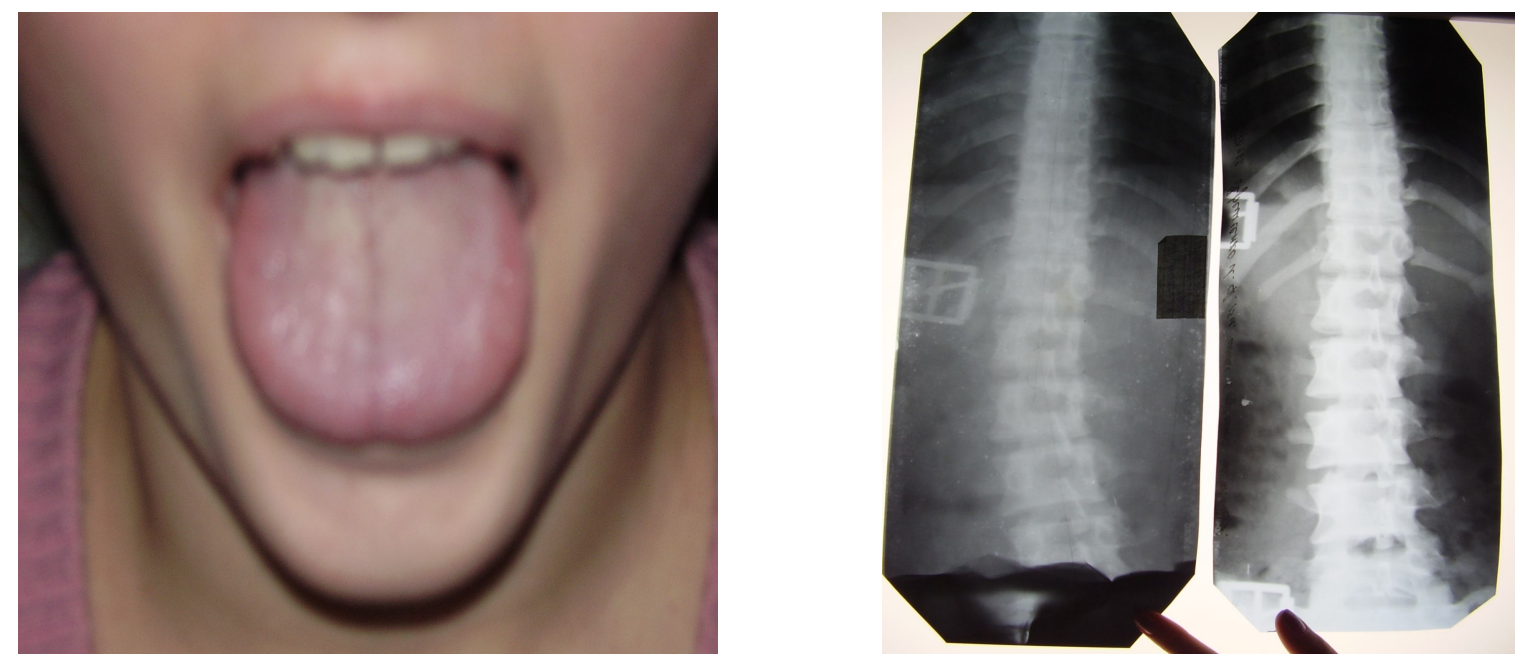

Fig. 2. Patient M., 12 years. Distortion of the middle line of the tongue in the middle portion corresponds to the distortion of the spine in the thoracic region.
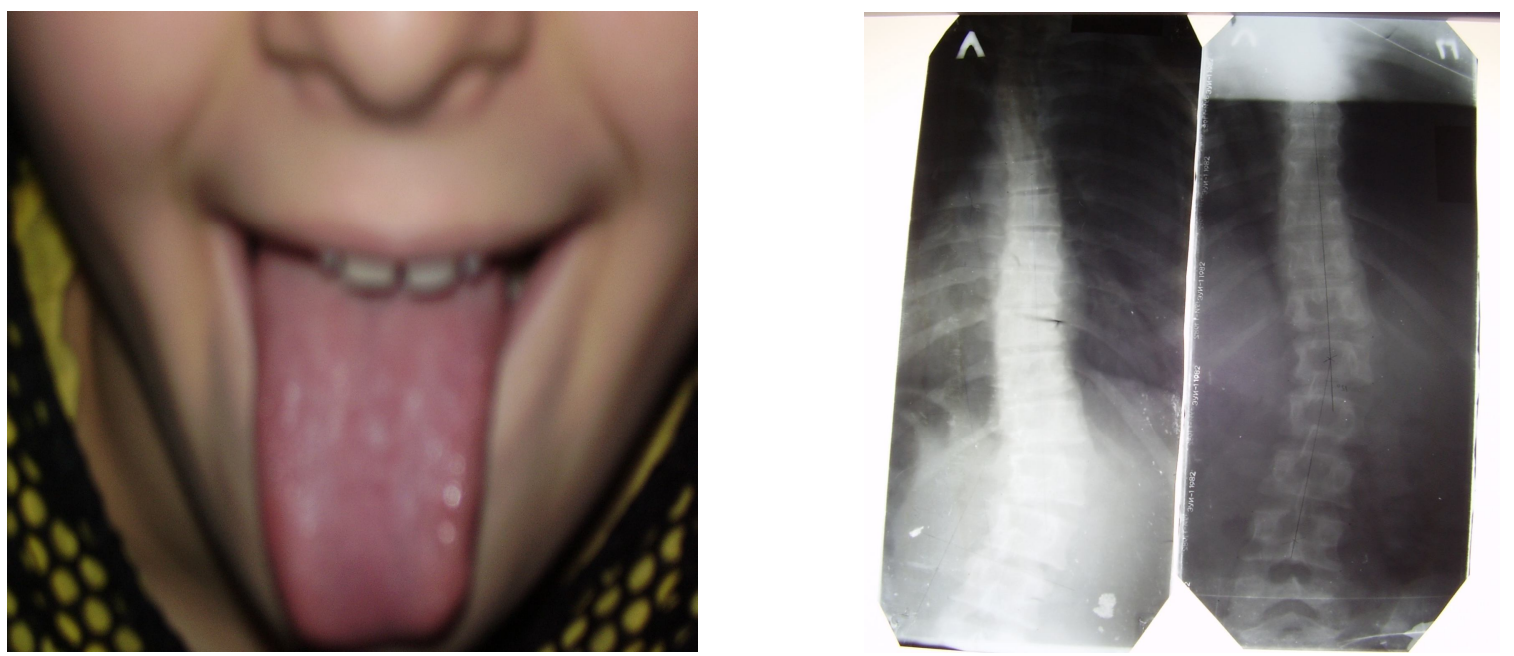

Fig. 3. Patient K., 10 years. Distortion of the middle line of the tongue in its upper third area corresponds to the distortion of the spine in the lumbar region. 

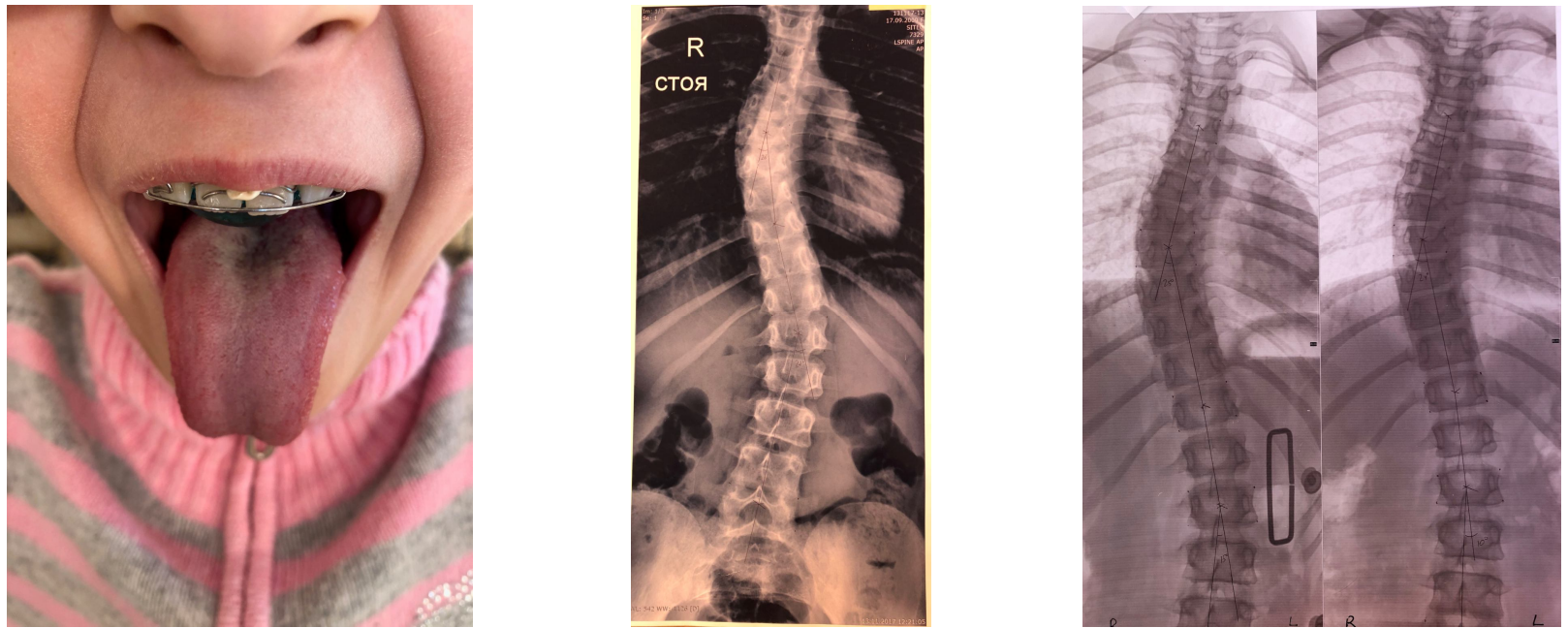

Fig. 4. Patient Y., 11 years. S-shaped distortion of the middle line of the tongue corresponds to the diagnosis: idiopathic S-shaped right-side thoracic, left-sided lumbar scoliosis of the second degree.

\section{Conclusions}

Observation data give us the right to conclude that dentists can suspect the presence of spinal deformation without general examination and X-ray examination in patients with the disease duration period of at least 2-3 years during the preventive examination of children and adolescents.

This research allows us to recommend paying attention not only to the size, color, state of the papillae of the tongue, but also to the position of the middle line, whose distortion may indicate the deviation of the vertebral column in different portions.

This study suggests further elucidation of the mechanism of influence of the vertebral column condition and skeletal muscles influence on the muscles of the maxillofacial area, which are involved in the formation of occlusion and function of oral cavity organs.

\section{References}

1. Antonenko Yu, Nesyn OF, Shnayder SA, et al. Oral mucosa diseases. Text book.; by ed. Borysenko AB. Odesa: Print house, 2015. 153-158.

2. Vorobyov Ye.O., Dudchenko MA, Zhdan VM Internal Diseases. Poltava: Divosvit; 2004. 175.

3. Danilevsky NF, Leontyev VK, Nesiy AF, Razhny Zhl. Diseases of the mucous membrane of the oral cavity. Moscow: OJSC Stomatology; 2001. 131-138.

4. Fleece PS, Dushin AI. The relationship of distal occlusion, morphological and functional disorders of the spine. Ukrainian Dental Almanac, 2015;1:75-77.

5. Ulitovskii S.B. Assessment of the tongue state. Dentistry maestro. 2006;4:39-45.

6. Racine MS, Skrypnikova TP. Propaedeutics of internal diseases. Poltava; 2001

7. Yumasheva G.S. Rheumatology and orthopedics. Moscow: Medicine; 1990. 215.

Матеріал надійшов до редакції 05.02.2019 p. 